\title{
Movement Capture or Movement Strategy? A Critical Race History Exchange on the Beginnings of Brown $v$. Board
}

\section{Megan Ming Francis \& John Fabian Witt*}

In 2019, Megan Ming Francis published a path-breaking article challenging the conventional wisdom in the field on a core piece of civil rights history: the role of a philanthropic foundation called the American Fund for Public Service, also known as the Garland Fund, in working alongside the NAACP to produce the organization's famous litigation campaign leading to Brown v. Board of Education. Starting in the late 1920 s and early 1930s, education came to occupy a central place in the $N A A C P$ 's agenda, and education desegregation became the focus of its efforts to break the back of Jim Crow. In Francis's provocative account, the predominantly white Garland Fund captured the agenda of the civil rights organization through its financial influence, shifting the organization's central focus from racial violence toward education equality. An organization that had been focused on protecting Black lives from white violence reoriented its attention to a new campaign, which siphoned off resources from other projects, such as workers' economic rights and Black labor concerns.

In this exchange, Francis and legal historian John Fabian Witt debate exactly who captured whom in the relationship between the NAACP and the Garland Fund. Their exchange engages method and substance in the history of civil rights. Among other things, Witt contends that the NAACP's leadership also subtly coopted the Garland Fund's resources and turned them toward the civil rights organization's preexisting objectives rather than vice versa. In Witt's account, the NAACP figured out how to advance its agenda through the Garland Fund, and the efforts of the two organizations became co-joined. The Francis-Witt debate has important implications for our understanding of the paths taken and not taken during

\footnotetext{
* Associate Professor of Political Science and Adjunct Professor of Law, Societies, and Justice, University of Washington; Allen H. Duffy Class of 1960 Professor of Law, Yale Law School. Professor Witt thanks Gillian Monsky and Ryan Howzell for their excellent research assistance.
} 
the civil rights movement, how social mobilization came to focus on formal legal doctrine rather than concrete social or political ends, and whether the law can truly be turned against systems of oppression. Whichever account is correct, the aftereffects of the NAACP-Garland Fund relationship still reverberate today.

The exchange proceeds with an opening statement by Francis, and reply by Witt, and a surreply by Francis, and a closing note from Witt.

\section{Dear John,}

The story behind the National Association for the Advancement of Colored People's (NAACP) campaign against segregated education that culminated in the landmark Brown v. Board of Education decision has been told many times before - and been told well. ${ }^{1}$ Standard treatments of the NAACP's education desegregation campaign often focus on Charles Hamilton Houston and Thurgood Marshall as well as the three-pronged litigation master plan they erected along with others at the NAACP. ${ }^{2}$ In this version of events, strategic decisions are venerated, Marshall is lionized, and victory in Brown seems to be the certain outcome of a carefully planned and executed litigation strategy. While pervasive and compelling, this narrative is incomplete. There is an incessant assumption, embedded in much of the civil rights literature, that education was the most logical way to break the back of Jim Crow. The belief is so powerful that many accounts of the civil rights movement begin in 1954 with the Brown v. Board of Education victory. However, the fact the NAACP mounted a campaign against segregated education and secured the most significant Supreme Court decision in civil rights law does not explain why it did so. Rarely asked is the important question: In a time in which racial discrimination permeated every aspect of American society - why did the NAACP choose to focus its litigation campaign on the area of education?

A major but under-recognized reason, I propose in a new study, The Price of Civil Rights: Black Lives, White Funding, and Movement Capture, is

1. Richard Kluger, Simple Justice: The History of Brown V. BOARD OF EduCATION AND BlaCK America's StrugGle for Equality (1975); KenNeth Mack, RePresenting the Race: The Creation of the Civil Rights Lawyer (2012); Charles Ogletree, All Deliberate Speed: Reflections on the First Half CENTURy of Brown V. BoARd of EduCATION (2004); JAMES Patterson, Brown v. Board of Education: A Civil Rights Milestone and Its Troubled Legacy (2001); Mark Tushnet, The NAACP's Legal Strategy Against Segregated EDUCATION, 1925-1950 (1987).

2. Note on terminology: The NAACP and the NAACP-Legal Defense Fund (LDF) are two separate organizations. The origins of LDF can be traced to the legal department that Charles Hamilton Houston helped to enlarge as part of the Garland Fund grant in the 1930s. In 1940, Thurgood Marshall (a protégée of Houston) established LDF as a separate legal entity due to tax concerns. It was not until 1957, after the Brown v. Board decision, that the LDF became independent from the NAACP. As a result of the timeline of the article, which focuses on the formulation of the grant, I will refer to the NAACP and not the LDF. Nevertheless, it is important to note that the Garland Fund had a lasting impact on the trajectory of both organizations. 
directly connected to movement capture- the process by which private funders use their influence in an effort to shape the agenda of vulnerable civil rights organizations. ${ }^{3}$ Drawing on economic theories of regulatory and state capture, I use capture as a way to understand how private funders operate like interest groups or private firms, to buy influence over the goals and strategies of activists and cause lawyers. According to this framework, funders are self-interested actors that can exploit their elevated financial position by linking provision of funds to the pursuit of new goals or by shifting the salience of existing agenda issues. The movement capture framework draws our attention to power asymmetries between wealthy donors and legal mobilization organizations that are in need of resources.

In the article, I argue the Garland Fund (known for funding the education desegregation litigation which culminated in Brown v. Board) engaged in a process of movement capture whereby it used its abundant financial resources to incentivize a shift in the NAACP's agenda away from racial violence to education. While I propose a contentious account, the traditional story of the Garland Fund's relationship with the NAACP is much more sanguine. The conventional story follows: the interests of the Garland Fund and the NAACP converged around the issue of segregated schools in the South and the Garland Fund bankrolled the litigation campaign. This funding story even has a fairytale ending: the collapse of legalized Jim Crow in the area of education. Unfortunately, this well packaged narrative hides a more complicated one: the marginalization of racial violence concerns from the NAACP's litigation agenda.

While there has been an important wave of studies focused on expanding the world of civil rights making and NAACP organizing before Brown $v$. Board, this time period is still significantly underdeveloped. ${ }^{4}$ Often, the NAACP's campaign against racial violence is either overlooked or dismissed as unrealistic in the context of Jim Crow America. To be clear, I am not asking a retrospective question about the feasibility of a racial violence campaign today; I am asking what looked possible from the standpoint of Black leaders at the NAACP in the time period before a formal legal campaign against segregated education was launched. My aim was to reconstruct the struggles between the NAACP and the Garland Fund as they

\footnotetext{
3. Megan Ming Francis, The Price of Civil Rights: Black Politics, White Money, and Movement Capture, 53 L. \& SOC'Y REV. 275 (2019).

4. For important studies see: TOMIKo BROWN-NAGIN, COURAGE TO DiSSENT: ATLANTA AND THE LONG History of the Civil Rights Movement (2012); Susan CARle, Defining the Struggle (2013);

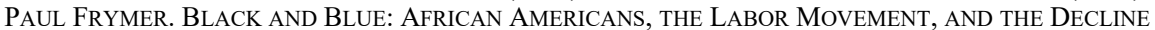
of the Democratic Party (2008); Risa Goluboff, The Lost Promise of Civil Rights (2007); JeFFrey Gonda, UnJust DeEds: The Restrictive COVENANT CASES AND THE MAKING OF THE CiVIL Rights Movement (2015); SOPHIA LeE, THE WorkPlace CONSTITUTION FROM THE NeW DEAL TO the New Right (2014); Kenneth Mack, Representing the Race: The Creation of the Civil Rights LAWYer (2012); LAURA WeInRIB, The TAMING OF FreE SPEECH: AMERICA's Civil Liberties COMPROMISE (2016).
} 
experienced them - using the actors' own language. It was to understand the NAACP's leadership as activists trying to chart the course of civil rights - rather than cast them as willing participants in an educationcentered civil rights movement from the outset. Widening the analytical lens helped to illuminate not just movement capture but also the broader framework of racial power and how it structured the actions taken by the Garland Fund elite as well as the more vulnerable NAACP leadership as they negotiated the future of civil rights. The focus on racial power owes to seminal scholarship in the field of critical race theory, which has long argued that the exercise of racial power is "systemic and ingrained" in legal institutions, discourse, and society. ${ }^{5}$ Critical race theorists have made plain that racial domination can be reproduced in liberal institutions by wellmeaning actors.

The article provides a historical case study on the NAACP/Garland Fund relationship from 1923 to 1930 . The timeframe is critical, as before 1923, the NAACP mounted the largest campaign in history against lynching and mob violence. Focused on the protection of Black lives from statesanctioned violence, the NAACP organized mass demonstrations, advocated for an anti-lynching bill in Congress, and won Moore v. Dempsey (1923), a landmark criminal procedure decision in the Supreme Court that reversed the death sentences of six African American men in Arkansas. According to the NAACP, the protection of Black lives from state and individual white violence was the pinnacle civil rights struggle of the 20th century. However, by 1925, the NAACP was severely underfunded and without a big donor to support its anti-lynching activism. ${ }^{6}$

Meanwhile, the Garland Fund was the vanguard of left wing philanthropy in the early twentieth century. The Fund began in 1922 after Roger Baldwin convinced Charles Garland to accept his \$1 million inheritance and put it to use in a national trust "directed to social and economic freedom" of the masses. Baldwin quickly assembled a board of directors that became a roster of notable white radicals: communists, labor activists, feminists, suffragettes, and socialists. And there was one African American: James Weldon Johnson. The stewards of the Garland Fund endeavored to

5. Derrick Bell, Race, Racism, and the Law (1972); Kimberle Crenshaw, Critical Race THEORY: THE KEY Writings THAT Formed THE MOVEMENT (1995).

6. For accounts of the development of the NAACP see the following: SuSAN CARLE, DeFINING THE Struggle (2013); Megan Ming Francis, Civil Rights and the Making of the Modern American State (2014); LANGSTON Hughes, Fight For Freedom (1962); 1 Charles Flint KELLOGG, NAACP A HiSTORY OF THE NATIONAL ASSOCIATION FOR THE ADVANCEMENT OF COLORED PEOPLE: 1909-1920 (1967); B. JoyCE Ross, J.E. SPINGARN AND THE RiSE OF NAACP, 1911-1929 (1972); PATRICIA Sullivan, LifT Every Voice: The NAACP AND THE MAKING OF THE Civil RightS MOVEMENT (2009). 
primarily impact the areas of labor and education. ${ }^{7}$

It is important to note that the battle against racist violence paved the way for the NAACP's later campaign against segregated education by establishing an important relationship with the Garland Fund and by showcasing the usefulness of courts in the struggle for equality. If the NAACP had not engaged in a national struggle to end lynching, there may have been no Brown because the relationship that led to the funding of the education desegregation campaign was established much earlier, when the NAACP was working against racial violence. The first grant and second grant from the Garland Fund occurred in 1922 and 1923 to support the NAACP in its anti-lynching campaign. In other words, the publicity the NAACP garnered from its national work in the anti-lynching campaign drew the attention of the Garland Fund and led to a grant of $\$ 2,500$ and an additional appropriation of $\$ 865.50$ to provide publicity to assist in passing the Dyer Anti-lynching Bill in Congress. ${ }^{8}$ Subsequently, ads were taken out in major newspapers across the United States to urge readers to contact their senators in support of the anti-lynching bill.

A few months after the anti-lynching bill died in a Senate committee, the importance of litigation was impressed upon the Garland Fund after the NAACP's Supreme Court victory in Moore v. Dempsey. As one of the NAACP's leaders would write afterward, "The Supreme Court decision in this notable case thus becomes one of the milestones in the Negro's fight for justice - an achievement that is as important as any event since the signing of the Emancipation Proclamation." The Moore victory was almost everything the Garland Fund wanted from its grantees: it was a decision of tremendous national significance and brought about by an oppressed minority. The only aspect it was missing was an explicit focus on organized labor or education: the two areas the Garland Fund was most interested in supporting.

The Garland Fund's issue priorities presented a unique set of hurdles to the NAACP as they did not seamlessly map onto the NAACP's agenda. In fact, it appeared as if the central interests of the two organizations were misaligned. By 1924, the NAACP was mostly concerned with racial violence not education - to the extent that education-related issues were rarely mentioned in board meetings. NAACP board minutes are particularly elucidative (see TABLE 1 below), showing how the NAACP mostly focused on racial violence every year from 1911 to 1931. Even local

7. Statement of Policy (Aug. 10, 1922) (on file with American Fund for Public Service Papers [hereinafter AFPS Papers], reel 2).

8. An appropriation of $\$ 2,500$ was voted on October 11, 1922 for an educational campaign in connection with the Federal Anti-Lynching Campaign. An additional appropriation of $\$ 865.50$ was voted on and approved on January 24, 1923. Applications Favorably Acted Upon (on file with AFPS Papers, reel 10, box 15).

9. Walter White, The Defeat of Arkansas Mob Law, 25 THE CRISIS 259, 261 (1923). 
NAACP branches were mostly concerned about racial violence as evidenced by an increase in letters and local branch reports. However, after 1931 there is a sharp shift as education issues take on increased importance for the NAACP's Board of Directors. To understand why education comes to occupy the majority of the NAACP's agenda after the 1930s, it is important to focus on the inner workings of the Garland Fund.

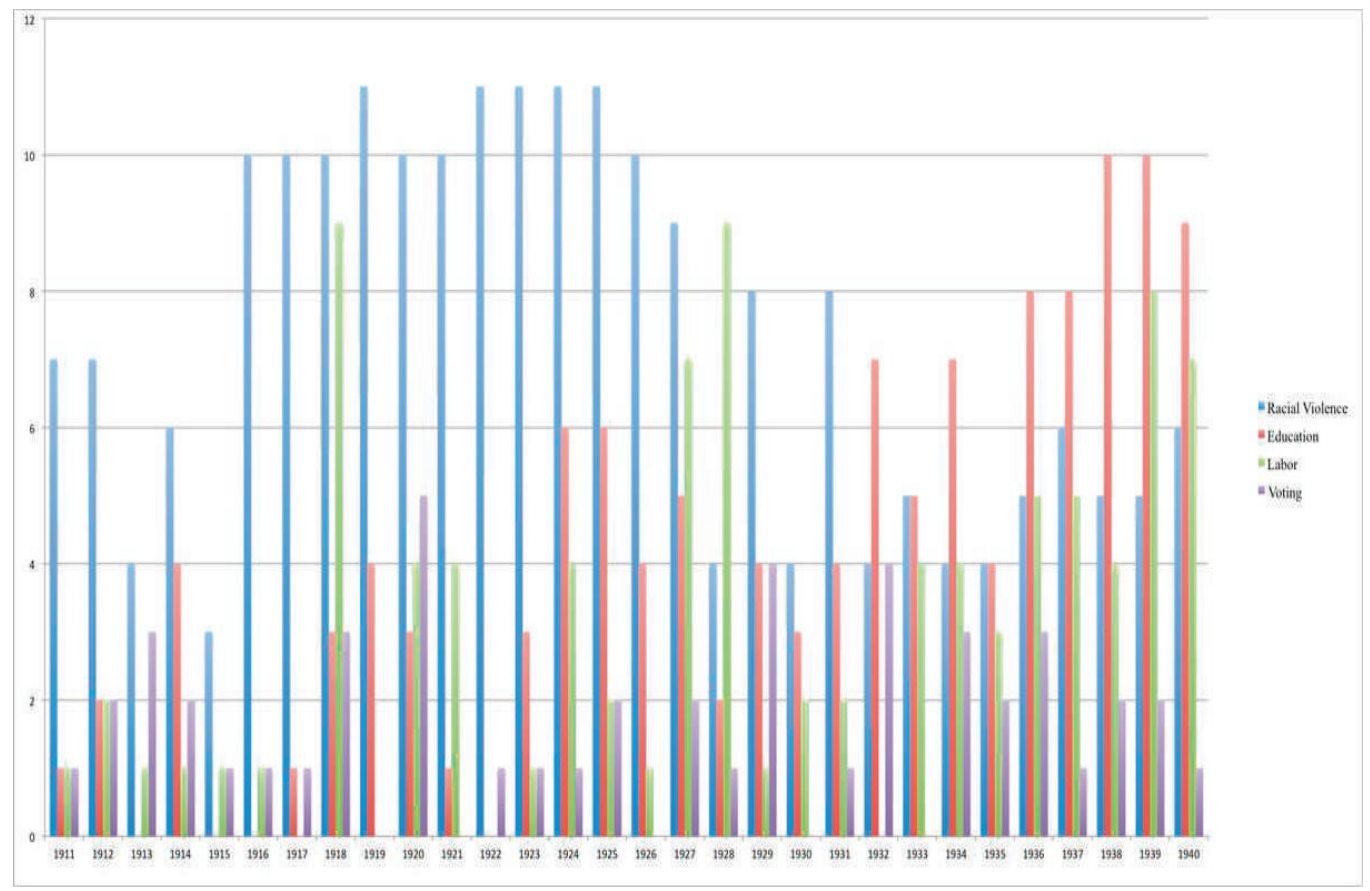

TABLE 1: NAACP Monthly Board Minutes, Mentions of the Important Issue Areas ${ }^{10}$

Even with the noblest intentions, funding radical causes and direct action does not always lead to tangible results. Between 1923 and 1929, members of the board of directors were feeling uninspired about the impact of the Garland Fund's existing grant portfolio. To help remedy this enthusiasm gap, the Board of Directors decided to revise its grant making policy in May 1929. It was agreed by all members to no longer accept grant applications

${ }^{10}$ Minutes of the Board of Directors 1911-1940 (on file with NAACP Papers, reel 1). 
"but only projects sponsored by members of the board or its committee." Further, it was determined "the board should select its major projects through special committees which shall be responsible for proposing expenditures covering the different fields." 11 This shift in the Garland Fund's grant-making process from responding to applications from grantees to designing programs for grantees set the Garland Fund and the NAACP down a new path of civil rights development.

Very quickly, civil rights emerged as a priority issue and litigation as a central strategy. Civil rights, the Garland Fund reasoned, was an ideal area to have a revolutionary impact and the NAACP was perceived to be the most effective civil rights legal organization in the country - a reputation garnered through its anti-lynching activities. In theory, drafting a project proposal was to be a collaborative process between the Garland Fund and the NAACP - in reality, the Garland Fund wielded a lot of influence over the NAACP due to its vast financial resources. The Garland Fund's initial plan was to give the NAACP a hefty grant of $\$ 100,000$ to fund a series of lawsuits in four areas of racial discrimination: education, Jim Crow cars, jury discrimination, residential segregation. However, with the downturn in the stock market, the eventual grant was reduced to a third of the original grant and only one issue remained: school segregation. ${ }^{12}$

Throughout the process of developing this plan, the NAACP's Walter White and James Weldon Johnson protested the emphasis away from racial violence to education in numerous ways. ${ }^{13}$ However, in a Jim Crow world, where white men and women controlled the purse strings, White and Johnson understood their place in the racial hierarchy and the importance of compromise- even if it was unbalanced. If education was the area where funding was available, the NAACP would expand its activism around education. And after all, the NAACP cared deeply about segregated education; it simply was not at the top of the organization's agenda.

In the end, the education desegregation campaign proved to be both more and less than the Garland Fund or the NAACP envisioned. The increased focus on education had the unintended impact of reducing the NAACP's activism around issues related to racial violence and the campaign around workers' economic rights in the 1930s and 1940s. However, the campaign also had the effect of dramatically transforming constitutional law with the

11. Minutes of the Board of Directors (May 14, 1929) (on file with AFPS Papers, box 2, reel 2).

12. Memorandum from Baldwin to Members of the Board (Oct. 18, 1929) (on file with AFPS Papers); Letter (June 12, 1933) (on file with AFPS Papers, reel 23).

13. Letter from Walter White, NAACP, to James Weldon Johnson, NAACP (Mar. 10, 1930) (on file with NAACP Papers, AFPS, Chronological File, 1922-1935, I C: 196); Letter from James Weldon Johnson, NAACP, to Walter White, NAACP (Mar. 11, 1930) (on file with NAACP Papers. AFPS, Chronological File, 1922-1935, I C: 196); Letter from Walter White, NAACP, to Morris Ernst, The Garland Fund (Mar. 13, 1930) (on file with NAACP Papers. AFPS, Chronological File, 1922-1935, I C: 196); Memorandum from White to Committee on Negro Work (Sept. 13, 1933) (on file with AFPS Papers, reel 23). 
momentous Brown v. Board of Education decision.

In the final analysis, it is my contention that the relationship between the Garland Fund/NAACP resembles one of movement capture more than that of collaboration. Archival records reveal that education was never universally accepted as the centerpiece issue for the NAACP's Black leadership but the organization was caught in a difficult bind between the desires of white liberals, a foundation with valuable resources, and the urgent needs of their own racial group. Of course, the NAACP was not alone in negotiating for greater control of its agenda with funders. SNCC, CORE, and many organizations large and small fought and sometimes split over questions of white influence over radical Black politics including, specifically, the role that foundations would play in financing and shaping the struggle. ${ }^{14}$ Rather than listen and engage in collective action problem solving with grantees, funders often view themselves as the grand architects of progress. Recognition that funders have been able to exert control over grantee agendas is useful in understanding how relations of power inequality become reproduced within purportedly progressive legal movements.

Lastly, it is important for me to state that in no way am I arguing that education was not a radical issue or that the NAACP did not care about education. Education was (and still is) a transformative civil rights issue. My disagreement is about the portrayal of the relationship between the Garland Fund/NAACP around the development of the grant. It is not enough that important issues are being addressed; the process matters and those most acutely impacted should be the drivers of movement strategy and goal formation.

I suspect that you have a different interpretation about this relationship, and for that reason, I am greatly looking forward to this dialogue!

Yours,

Megan

14. Robert Allen, Black Awakening in Capitalist America: An AnAlytic History (1969); Karen Ferguson, Top Down: The Ford Foundation, Black Power, and the Reinvention of RaCial Liberalism (2013); Maribel Morey, Born in Colonial Africa: The RoOts of an AMERICAN Dilemma (forthcoming 2020); ALdON Morris, THE ORIGINS OF THE CIVIL RightS Movement (1986); Noliwe Rooks, White Money/Black Power: THe Surprising History of AFRICAN AMERICAN STUDIES AND THE CRISIS IN HIGHER EDUCATION (2006); TIFFANY WILLOUGHBY-

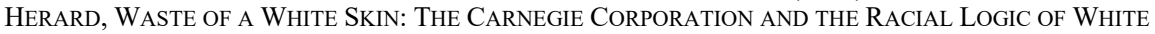
Vulnerability (2015); KeEANGa-YamahtTa TAYlor, From \#BlackLivesMatter to Black LIBERATION (2016). 


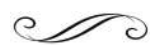

Dear Megan,

Wow, your new work on the Garland Fund and the NAACP shakes the conventional story of American civil rights to its core. As far as I'm concerned, it is the best work about the Fund and the NAACP since at least the classic work of Merle Curti in 1959, and maybe ever. ${ }^{15}$ I'm hardly alone in finding your work on the subject compelling. ${ }^{16}$ I'm certain its influence will continue to spread in the coming months and years.

At the heart of your inquiry is the question of how education became a centerpiece (the centerpiece?) of the twentieth-century NAACP program when there were so many desperate injustices and crying needs crowding onto the civil rights agenda. You posit that the education campaign that eventually produced Brown v. Board was not actually the NAACP's agenda at all, at least not originally. In your account, the prominence of education was a result of the organization's capture by white liberals who led men like James Weldon Johnson and Walter White into abandoning their uncompromising program to stop violence against African-Americans. In its place they adopted a less controversial program of education rights. Along the way, you insist that we ask hard questions about the "production of civil rights knowledge" and about how funders "exert influence over the agenda of Black activists." 17

Like many of your readers to date, I share your sense that the question of how education emerged as the leading civil rights program of the era usually goes unasked. With rare exceptions, as you note, scholars in law and legal history typically fail even to see that education's emergence is a phenomenon that needs to be explained. ${ }^{18}$ (Education historians, interestingly, make no such mistake. ${ }^{19}$ ) You boldly suggest that behind this failure in the literature lies a desire by white historians to tell a story about civil rights that is "respectable and credible" and that effaces some of the

15. Merle Curti, Subsidizing Radicalism: The American Fund for Public Service, 1921-41, 33 Soc. SERV. REV. 274 (1959).

16. E.g., Kelsey Piper, How 'Movement Capture' Shaped the Fight for Civil Rights, Vox (Feb. 28, 2019), https://www.vox.com/future-perfect/2019/2/28/18241490/movement-capture-civil-rightsphilanthropy-funding; Matthew Grossman, How Philanthropy Diverts Social Movements, NiSKANEN Center Science of Politics Podcast (Mar. 13, 2019), https://www.niskanencenter.org/howphilanthropy-diverts-social-movements; Amy Costello, How Philanthropy 'Captures' Social Movements, NONPROFIT Q. (Mar. 22, 2019), https://nonprofitquarterly.org/how-philanthropy-capturessocial-movements.

17. Francis, supra note 3, at 281.

18. A leading exception is Risa L. Goluboff, The Lost Promise of Civil Rights (2006).

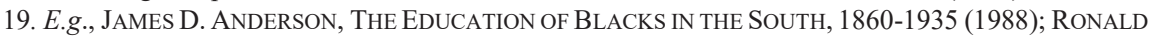
E. BUtCHART, NORTHERn SCHOOls, SOUTHERN BlaCKS, AND RECONSTRUCTION: FreEDMEN'S EdUCATION, 1862-1875 (1980); AdAM FAIRCLOUGH, A ClASS OF THEIR OWN: BLACK TEACHERS IN the Segregated South (2007); Heather Andrea Williams, Self-Taught: African American EDUCATION IN SLAVERY AND FREEDOM (2005); 
most brutal dimensions of the white supremacist regime of Jim Crow.

Sign me up for each of these parts of your story. The literature on civil rights history will have to make substantial new room for your important arguments and ideas.

Here's what I don't quite understand. You tell the story of the turn to education as if it were a fall from grace: a fateful decision by the leading civil rights organization in the country to pursue misleading liberal panaceas in a world of violent oppression. My reading of the archives, however, leads me to see a story of creativity and agency. Where you see the capture of the NAACP, I see the NAACP coopting the Garland Fund. I don't want to be naïve. I sure don't want to make the mistakes of white liberals before me. But I see genius and agency where you see victimhood. W. E. B. Du Bois, James Weldon Johnson, and Walter White, I think, acted forcefully and effectively. For better and for worse, they slyly changed the Garland Fund's program. The Fund's directors subtly redirected the NAACP, to be sure. But the Fund did so not by encouraging an education agenda, but by pushing the NAACP toward a more radical position on economics and labor. In what follows I offer some of the evidence that has led me to this different, though not entirely incompatible, view.

The American Fund for Public Service, better known as the Garland Fund, aimed from the start, as you say, to support labor organizing ("producers' movements") and to work for "the protection of minorities" through publicity and legal defense. In the Fund's first weeks, it supported the NAACP's effort to swing public opinion behind the anti-lynching bill then before the Senate. Two and a half years later, the Fund financed the NAACP's defense of Ossian Sweet, the Black doctor in Detroit who was prosecuted for murder when he defended himself, his friends, and his family from a race riot on the front lawn of the home he had purchased on a white block. The Fund also backed the NAACP's first effort to raise funds for legal defense, designed to protect African Americans from violence and miscarriages of justice. ${ }^{20}$

Education, by contrast, was a field the Garland Fund avoided as best it could. The Fund's directors rejected application after application from educational programs. ${ }^{21}$ Roger Baldwin, the most active member of the

20. Keven Boyle, Arc of Justice: A Saga of Race, Civil Rights, And Murder in the JazZ Age (2004); Gloria Garrett Samson, The American Fund For Public Service: Charles Garland AND RADICAL PHILANTHROPY, 1922-1941 (1996).

21. See, e.g., Letter from B.D. McDougall to American Fund for Public Service (Apr. 1923) (on file with American Fund for Public Service Records [hereinafter AFPSR], box 49, reel 31) (rejecting proposal for experimental program in the Valparaiso public schools); Letter from Harry Kelly to Roger Nash Baldwin (July 14, 1923) (on file with AFPSR, reel 30) (complaining of unfavorable treatment of grant application by the Ferrer School in New Jersey); Letter from Roger Nash Baldwin to Charles J. 
Fund's board of directors, explained to one such applicant in 1924 that education was outside the scope of the Fund's work. ${ }^{22}$ An internal policy memo at the Fund later that year questioned whether education for children was within the Fund's mandate at all. ${ }^{23}$ Progressive educators reacted incredulously and urged Baldwin and other directors to change their stance. ${ }^{24}$ But the Fund stuck to its position.

The Fund's directors were especially resistant to making educationrelated grants when it came to Black education in the South. The Fund's directors explained that there were "already agencies in the field aiding Negro education." ${ }^{25}$ A survey commissioned by the Fund concluded that "negro schools" in the South were well-funded thanks to foundations like the Rockefeller-affiliated General Education Board and the Rosenwald Fund. ${ }^{26}$ There was a deeper problem, too: leading African American educators rarely shared the radical politics of the Fund's directors.

How, then, did the directors of the Garland Fund eventually finance Brown v. Board if they opposed funding efforts to improve Black education per se? How did they come to help finance a civil rights campaign organized around education? The answer lies in a well-orchestrated lobbying campaign by Du Bois, Johnson, and White. The leaders of the NAACP captured the white liberals and radicals at the Fund, not vice versa.

By the middle of the 1920s, the leaders of the NAACP thought they had beaten back the worst of the lynching problem. To be sure, the Dyer antilynching bill had failed in the Senate. But the Garland Fund-sponsored publicity campaign around the bill seemed to have had substantial effect. At least James Weldon Johnson thought so in 1924, when he cited the NAACP's propaganda efforts for the decline in lynchings from sixty-eight in 1922 to twenty-eight in 1923 and only three in $1924 .{ }^{27}$ In 1926, the organization marked its sense of success in this field when it transferred its remaining anti-lynching publicity funds - a balance of $\$ 2,500$ left over from the Garland Fund's 1922 and 1923 anti-lynching grants - to a savings

Rhoades (1924) (on file with AFPSR, box 51, reel 32) (rejecting application from Rhoades Ranch School in Cody, Wyoming).

22. See, e.g., Letter from Roger Nash Baldwin to John Edelman (Feb. 26, 1924) (on file with AFPSR) (reporting that "other things seem more important to practically all the members of this Board").

23. Roger Nash Baldwin, A Few Questions Concerning Our Policy Which May Serve Members of the Board of Directors in Preparing Memos (Dec. 1924) (on file with AFPSR, reel 1).

24. Letter from Henry B. Linville to AFPS (1925) (on file with AFPSR, reel 33).

25. Letter from A. T. McKinney, Houston Industrial Training School, to AFPS (1923) (on file with AFPSR, box 48, reel 30).

26. The Labor Bureau, Inc: Survey (on file with AFPSR, box 7, reel 4).

27. James Weldon Johnson, Lynching - America's National Disgrace, CuRRENT HIST. 596-601 (January 1924). 
account so that it would accrue interest for future use. ${ }^{28}$

At virtually the same time, leading African American intellectuals in and out of the NAACP made a turn to education for a number of reasons independent of any philanthropic foundation. Alain Locke, for example, decided in 1925 that the time had arrived for a new movement for Black education. ${ }^{29} \mathrm{Du}$ Bois had been pressing for education for more than a decade. ${ }^{30}$ (For just as long, he had openly disdained the philanthropists who supported Black education in the South. ${ }^{31}$ )

A number of considerations prompted the turn toward education. The Republican Party's "lily white" strategy of the 1920s had closed off electoral politics as a path for civil rights; no realistic chance arose for another anti-lynching bill in the Congress until the New Deal. ${ }^{32}$ The cultural and literary politics of the Harlem Renaissance emphasized the power of intelligent Black culture. ${ }^{33}$ Specific controversies drew attention to education, too. In 1921 and 1922, the Smith-Towner bill, which would have created new federal funding for education, proposed to distribute school resources through state authorities in such a way as to allow southern states to discriminate between Black schools and white ones. ${ }^{34}$ As African Americans moved from South to North in the Great Migration, new segregation efforts arose in northern towns like Gary, Indiana, and Toms River, New Jersey. ${ }^{35}$

The brilliant strategy of the NAACP leadership was to package its preexisting education strategy in the kinds of class- and labor-based terms the directors of the Garland Fund would find compelling. Approaching the Fund for a grant to support a study of racial inequality in the funding of public schools in the South in late 1924, Du Bois asserted that "Negroes form a large and increasingly important part of the laboring class in the United States." 36 Johnson added that assistance to Black schools would help Black children "to become as rapidly as possible an integral factor in the industrial and labor world." 37 Du Bois made the point directly in a grant

28. RoBert L. ZANGRANDo, The NAACP CRUSAdE AGAINST LyNCHING, 1909-1950, at 84 (1989).

29. Alain Locke, Negro Education Bids for Par, 54 SURV. GRAPHIC 567 (1925). See generally JEFFREY C. Stewart, The New Negro: The Life of Alain Locke 499-503 (2018) (describing Locke's new turn to liberal arts education for Black Americans).

30. W.E.B. Du Bois, The COMmon School AND the Negro American (1911); W.E.B. Du Bois, The

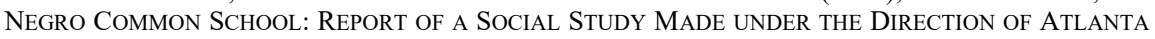
UniVERSITY (1901); W.E.B. Du Bois, Negro Education, 15 THE CRISIS 173 (1918).

31. See, e.g., W.E.B. Du Bois, Gifts and Education, 29 THE CRISIS 151 (1925).

32. JOSHUA FARRINGTON, BLACK REPUBLICANS AND THE TRANSFORMATION OF THE GOP 17 (2016); NANCY J. WEISS, FAREWELL TO THE PARTY OF LINCOLN 5-6 (1983).

33. DAVid LeVering LeWis, When Harlem Was in Vogue (rev. ed. 1997).

34. Patricia Sullivan, Lift Every Voice: The NAACP and the Making of the Civil Rights MOVEMENT 129-30 (2009).

35. Davison M. Douglas, Jim Crow Moves North: The Battle over Northern School DESEGREGATION, 1865-1954 (2005).

36. Letter from W.E.B. Du Bois to AFPS (Nov. 9, 1924) (on file with AFPSR, reel 7).

37. Letter from James Weldon Johnson to Roger Nash Baldwin (May 15, 1924) (on file with AFPSR, 
application in early 1925: "If now the Garland Fund wishes to encourage organized labor among Negroes it must encourage intelligence among Negroes. Negro education is today fatally deficient because of the lack of elementary education in the South. The first step toward labor organization among Negroes on any definite and lasting scale must be to reveal the plight of the Negro common school." 38

Baldwin and other directors of the Fund did not immediately concur. When Du Bois sought funding for his educational funding studies at the NAACP's journal The Crisis, the Fund directors at first demurred. Baldwin reminded Du Bois that education was outside the Fund's field of activity and checked into alternative sources of funding with more traditional financiers of Black education in the South. ${ }^{39}$ The big foundations had no interest in supporting Du Bois. ${ }^{40}$ An insider at the Fund recommended against granting Du Bois's application because of Du Bois's reputation for "creating antagonism on the part of the white South."41 Eventually, however, the Fund came around, on the condition that Black education "have the effect" Du Bois predicted it would for Black labor organizing. The NAACP's labor-oriented account of education had won the day and turned the Fund to education. ${ }^{42}$

The same reasoning supported the NAACP's proposal for a desegregation campaign four years later. The Fund worried that the NAACP had "no labor program." 43 Du Bois replied that grants to The Crisis and the NAACP would "lead[] the race into industrial democracy and emancipation from their present peonage." 44 As Walter White explained in 1930, the Fund's big desegregation grant aimed "to establish conditions and a psychology which will put the Negro laborer, industrial and agricultural, upon an equal basis as regards organization with white labor."45

The NAACP's co-optation of the Fund did not prevent influence from running the other way, to be sure. The process of applying for education-

reel 2).

38. Memorandum from W.E.B. Du Bois to Mr. Johnson (Jan. 15, 1925) (on file with AFPSR, box 49, reel 31), https://credo.library.umass.edu/view/full/mums312-b030-i079.

39. Letter from Roger Nash Baldwin to W.E.B. Du Bois (Nov. 28, 1924) (on file with AFPSR, reel 7); Letter from Roger Nash Baldwin to James H. Dillard (Dec. 4, 1924) (on file with AFPSR, reel 7).

40. Letter from James H. Dillard to Roger Nash Baldwin (Dec. 17, 1924) (on file with AFPSR, reel 7); Letter from T. J. Woofter, Jr. to James H. Dillard (Dec. 15, 1924) (on file with AFPSR, reel 7).

41. Letter from L. Hollingsworth Wood to Roger Nash Baldwin (Jan. 27, 1925) (on file with AFPSR, reel 7).

42. Letter from Roger Nash Baldwin to W.E.B. Du Bois, (Jan. 29, 1925) (on file with AFPSR, reel 7).

43. Memorandum from Walter White to W.E.B. Du Bois (Jan. 23, 1930) (on file at https://credo.library.umass.edu/view/full/mums312-b055-i160).

44. Letter from W.E.B. Du Bois to James Weldon Johnson (Dec. 20, 1929) (on file at https://credo.library.umass.edu/view/pageturn/mums312-b183-i015/\#page/1/mode/1up).

45. Letter from Walter White to A. Philip Randolph (Oct. 7, 1930) (on file with AFPSR, box 54, reel 34); see also Memorandum from Committee on Negro Work to the Directors of the American Fund for Public Service (on file with James Weldon Johnson and Grace Nail Johnson Papers, Beinecke Library, Yale University (JWJP), box 1, folder 14). 
related financing from the Fund nudged the African American NAACP leadership toward a left-leaning labor and class-oriented politics. At the beginning of the 1920s, Mary White Ovington, a white member of the NAACP's board of directors, had bemoaned the economic conservativism of James Weldon Johnson. ${ }^{46}$ By the latter part of the decade, Johnson had learned to appeal to the radicalism of socialist and communist members of the Fund's board in supporting grant proposals from African American applicants. He did not share their politics. Not by a long shot. But he and White had learned something of the value of labor. A few short years later, Du Bois would soon make his storied turn to Marxism and Black economic nationalism. ${ }^{47}$

Undoubtedly there were lines of mutual influence running between the NAACP and the Garland Fund. I've tried to describe some of them here ever so briefly. I fear I've gone on too long!

One more observation for now: do you worry that the theory of movement capture sells the NAACP too cheaply? For sure you're right that the organization was strapped for cash in the 1920s. But the Garland Fund and its million dollars (two million eventually, after stock market growth in the 1920s) did not have hugely deep pockets, at least not for a philanthropic foundation. I'll have more to say in my next contribution comparing the Garland Fund to the giant foundations of the era. But regardless, the Garland Fund never offered the NAACP all that much money. The initial award may have been an eye-popping $\$ 100,000$. Ultimately, after the stock market crash of 1929 decimated its remaining resources, the Fund ended up contributing something more like $\$ 30,000$ to the desegregation campaign. Can a foundation buy a social mobilization as big and important as the civil rights movement for a sum this tiny? Could philanthropists turn the heads of people as serious as Johnson and White for a sum spread over five or six years that amounted to only a third of the NAACP's $\$ 50,000$ annual budget?

That would be truly extraordinary - unless, as I suspect, the NAACP's savvy leaders managed to get a good deal back in return.

I'm interested to hear what you think!

Yours,

John

46. Eugene LeVy, James Weldon Johnson: Black Leader, Black Voice 185 (1973).

47. DAVId LeVering Lewis, W.E.B. Du Bois: The Fight For EQuality and the American CEnTURY, 1919-1963 (1993). 


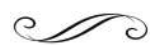

Dear John,

Whew! Ok, that is a lot to unpack especially in a forum where I have so little room.

But before doing so, I want to let you know how much I have enjoyed disagreeing with you on parts of this story over the past few years. Instead of being dogmatic, you have persistently asked "why" in a desire to understand my perspective and not entirely to disprove. In my attempts to answer the "why" at conferences and in this written dialogue, I've been pushed to reexamine my assumptions, the literature, and the archives. In the end, your critique made the article stronger and our continual (it won't end here) disagreement has proved productive in thinking through larger themes in legal history such as historical methodology, racial capitalism, and the role of philanthropies as legal intermediaries.

Within a constrained word limit, you crafted a magisterial narrative of the Garland Fund and the NAACP. Your work takes us further than previous studies that utilize a resource mobilization framework in proposing that education was where the NAACP and Garland Fund's interests intersected. Instead, you propose that the NAACP's agenda is not captured by the Garland Fund nor do the interests of the organizations conveniently overlap; in your analysis, the NAACP captures the Garland Fund and redirects their funding into a direction that they were not initially willing to go. According to you, it was the lobbying prowess, the steadfast will, and genius of James Weldon Johnson, Walter White, and W.E.B. Du Bois to push for a campaign centered on education desegregation that ultimately convinced the Garland Fund to support its historic education desegregation campaign. You are well situated to make this claim as your historical excavation of the Garland Fund has no equal.

Yet, this redemptive account is at times deeply contradictory with my own. I have spent a long time thinking about how we have come to such radically different conclusions regarding the formation stage of the NAACP's campaign against segregated education - especially given that many of the documents we used to construct our narratives are the same (though I spent more time in the early NAACP documents and you have spent more time in the later Garland Fund archives). I suspect that what might partially drive this disagreement are different methodological approaches to archive materials.

Admittedly, I read the archives for this article differently than I did for my first book on the NAACP's anti-lynching campaign. Since that time, I have read the works of many postcolonial and feminist scholars who have 
transformed my orientation to archival research by drawing my attention to the way power operates in archives and how it influences the decisions that researchers make in the process of narrative formation. ${ }^{48}$ I read for what was there and for what was not there; I attempted to read both sets of archives in the context of Jim Crow racial dynamics; and, in an act of historical reparations, I centered the perspective of the NAACP's leaders above that of the Garland Fund's directors. This critical historical method allowed me an opportunity to learn that disagreement and cooptation rarely look or sound like how we think they should. In other words: by reading the archives differently ... I heard differently.

The historical methodology questions that animated my research include: How do we confront and write about a history of civil rights lawmaking that has been recorded during periods of severe economic inequality and white supremacy? How do we tell stories of Black people trying to construct a vision of civil rights before there were substantive civil rights legal guarantees? And finally: How do we interrogate top-down sources to tell stories from the bottom up?

I also tried to think through what "code switching" sounded like in the late 1920s, and by that I mean how Black people change what they say and how they talk when white people are around and or when they think white people are listening. I did this to account for Du Bois's theory of "double consciousness," which he described as "the sense of looking at one's self through the eyes of others," and in particular, the need for Black people to constantly think about how they are perceived by non-Black people. ${ }^{49}$ If we believe Du Bois, then how might we incorporate his double consciousness theoretical framework into our archival analysis of this period? How does it disrupt and challenge how we traditionally read archives?

Myself, and the majority of Black people I know, code switch today-so, surely, the NAACP's Black leaders practiced some variation of code switching in this earlier period when they interacted with white funders. This does not mean that I did not take everything at face value in the archives, but in my analysis, I probed deeper into the words that were written or spoken when they directly involved the Garland Fund.

One example that I would like to highlight revolves around how to interpret Walter White's response to Morris Ernst (whom, I argue, led the education charge at the Garland Fund). When pressed by Johnson on why he had not written Ernst back, White responded: "At last here is the

48. LiSa Lowe, The Intimacies of Four Continents (2015); Michel-Rolph Trouillot, Silencing the Past: Power and the Production of History (1st ed. 1995); AnN Laura Stoler, Along the Archival Grain: Epistemic AnXieties And Colonial Common Sense (2009); Saidiya Hartman, Venus in Two Acts, 12 Small AXE, no. 2, 1-14 (2008); Stephanie Smallwood, The Politics of the Archive and History's Accountability to the Enslaved, 6 Hist. PRESENT: J. CritiCAl Hist., no. 2, 117, 117-132 (2016).

49. W.E.B. Du Bois, Souls of Black FolK: EsSAYS AND SKetches 351 (1903). 
Memorandum drafted along the lines which you suggested. This is only a rough copy for you, Lewis and Jim to use as a basis. I have no pride of authorship, so don't hesitate to speak frankly about it." ${ }^{50}$ Read on its own, it's a bit innocuous, but when read in consideration of the power dynamics at play and in context of the rest of White's correspondence over the previous decade (most of which is rapid and detailed), it is clear that he is signaling his disapproval with the process by declaring he has "no pride of authorship." In many ways, White embodies the frustration of Black voices in a Jim Crow racial order in which their perspectives are only made visible when they comport with white notions of rights making.

This brief explanation of my historical methodology is perhaps partly responsible for our divergences on two key aspects of the narrative that I would like to elaborate on. First, the marginalization of the NAACP's racial violence campaign and second, the impact of the Garland Fund in enlarging the education focus of the NAACP.

I am still unclear about how you explain the marginalization of the NAACP's racial violence campaign. In my reading, the NAACP's concern about lynching and mob violence did not diminish throughout the 1920s; a review of the Board of Director minutes reveals that racial violence was the issue the NAACP's leadership was discussing the most. ${ }^{51}$ And this should be no surprise because African Americans were still being lynched at staggering rates - it went down slightly between 1923-1928 but increased again during some of the years that cover the formation of this education grant. ${ }^{52}$ If anything, racial violence was the NAACP's flagship civil rights issue (talked about at national board meetings, local meetings, and in the pages of The Crisis). Thus, how could an issue at the forefront of the NAACP's agenda, at the core of the NAACP's identity (the organization was founded in response to a lynching), and championed by its leaders, simply fall away? And how did education - an issue that was certainly talked about by the NAACP's leadership, but to a significantly lesser degree than a host of other issues including racial violence, voting, and labor-rise to the top?

What did shift in the 1920s was the NAACP's strategy for fighting racial violence: it moved away from publicity campaigns to legal campaigns. Publicly, the NAACP claimed victory in their public opinion campaign but

50. Letter from Walter White to Morris Ernst (Mar. 28, 1930) (on file with NAACP Papers).

51. Megan Ming, The Price of Civil Rights: Black Politics, White Money, and Movement Capture $53 \mathrm{~L}$. \& Soc'y Rev. 1 (2019).

52. Douglass Ekberg, Reported Victims of Lynching by Race: 1882-1964, in HISTORICAL STATISTICS of the United States, Earliest Times to the Present (Susan B. Carter et al. ed., Cambridge Press millennial ed. 2006) (see table Ec251-253). 
privately they were frustrated with the slow pace of progress..$^{53}$ The NAACP had spent considerable resources in trying to shape the hearts and minds of white Americans, but after many years, those efforts yielded few results. In contrast, the Supreme Court victory in Moore v. Dempsey (1923) marked a significant turning point for the NAACP, and the organization immediately shifted to a courtroom strategy. ${ }^{54}$ One of the many lessons from Moore was the utility of law (versus publicity and legislation) as a tool to fight racial injustice. ${ }^{55}$ For example, at a 1923 board meeting, the NAACP announced the launch of a new legal defense fund, which aimed to raise $\$ 25,000-50,000.56$ And in the year after Moore was decided, the NAACP noted a considerable increase in legal defense for issues pertaining to racial violence. ${ }^{57}$ Specifically, the NAACP was concerned about coerced confessions, jury discrimination, and death penalty or "legal lynchings" of African Americans. And in much correspondence with the Garland Fund between 1924-1929, Johnson makes it clear that these issues were of vital importance-going so far as to rank these issues as of highest concern to the NAACP. ${ }^{58}$

You are absolutely right that the NAACP was becoming more concerned about education near the end of the 1920s. I'll even concede the NAACP was excited to build a litigation campaign around segregated education with financial support from the Garland Fund. I have no doubt that an educationfocused rights program was the most the NAACP could have gotten out of the Garland Fund. But up until the beginning of the negotiation around this grant, education was not at the top of the NAACP's agenda. And I cannot help but wonder, in a world — a different world — that did not limit the full arc of Black freedom dreams, what else could have been possible?

I have come to believe that a central reason why analyses of this earlier period overlook the significance of the NAACP's racial violence campaign

53. NAACP Anti-Lynching Committee, Meeting Notes, (Nov. 14, 1919) (on file with NAACP Archives, Manuscript Division, Library of Congress); Tenth Annual Report for the Year 1919 (on file with NAACP archives, Manuscript Division, Library of Congress).

54. Megan Ming Francis, Civil Rights and the Making of the Modern American State (2014); JAmes Weldon Johnson, Along This WAy (1938); PATricia Sullivan, LifT Every Voice: THE NAACP AND THE MAKING OF THE CIVIL RIGHTS MOVEMENT (2009).

55. Megan Ming Francis, Civil Rights and the Making of the Modern American State (2014). 56. Board of Director Minutes, (February 5, 1923) (on file with the NAACP Papers, Manuscript Division, Library of Congress).

57. Board Minutes (Feb. 5, 1923) (on file with NAACP Archives, Library of Congress); Fourteenth Annual Report for the Year 1923 (on file with NAACP Archives, Library of Congress); Fifteenth Annual Report for the Year 1924 (on file with NAACP Archives, Library of Congress).

58. Memorandum from James Weldon Johnson to the NAACP Board of Directors on Policy of the Fund as It relates to the Negro as a Minority Group, (Apr. 25, 1924) (on file with AFPS Papers); Letter from Johnson to Baldwin (May 15, 1924) (on file with AFPS Papers); James Weldon Johnson, Synopsis for Program (June 27, 1930) (on file with NAACP Papers. AFPS, Chronological File, 1922-1935, I C: 196). 
is largely a result of examining the NAACP through a purely racial lens. The widely held understanding of the NAACP follows roughly along these lines: the NAACP was a race organization, it frequently called out racial injustices, and the historic fight for education equality was waged over the color line. I'm not suggesting this interpretation is incorrect - the NAACP was an organization centered on fighting racism in America. However, viewing the NAACP through this narrow lens only tells us one part of the NAACP's story. Missing is how closely the NAACP tied its critique of racism to a critique of capitalism.

I hope the difference in how we assemble our narratives about the NAACP/Garland Fund relationship might open up room to think about how a focus on racial capitalism would transform analyses of this period and shift our conclusions. To be sure, the making of civil rights law is replete with analyses about how race and racism shape the development of constitutional law, but not enough analyses have worked through the role of race and capitalism. ${ }^{59}$

A focus on racial capitalism in the NAACP's early years brings the full complexity of the organization into view. Like many Black radicals of the time, the NAACP's leadership understood the racial inequality experienced by African Americans was deeply tied to the economic order. ${ }^{60}$ Because race is an issue that overwhelms, it has been rare for legal historians to locate a critical class analysis inside of the early NAACP. Instead, scholars such as yourself suggest interaction with the Garland Fund was instrumental in nudging the NAACP to develop a left-leaning labor and class-oriented politics. However, I think this perspective gives the Garland Fund too much credit.

Since at least the mass slaughter of African Americans in East St. Louis in 1917, and pushed forward by the racial pogrom during the red summer of 1919, the NAACP was actively engaged in Black organizing (around peonage labor and exploitative sharecropping contracts) in the South. Du Bois was constantly sounding the alarm in The Crisis about the hostility of white labor unions to Black workers. And, Moore v Dempsey, the case the NAACP spent 1919-1923 litigating, was ultimately about the legitimacy of Black workers organizing into labor unions. In other words, long before the Garland Fund came along, the NAACP had already tied a vision of racial justice to the undoing of the predatory capitalist state.

59. Notable exceptions include W. E. B Du BoIs, BLACK RECONSTRUCTION IN AMERICA (1935); RisA Goluboff, The lost Promise Of Civil Rights (2007); Sophia Lee, The Workplace Constitution From the New DeAL to the New Right (2014); Amna Akbar, Toward a Radical Imagination of Law, 93 N.Y.U. L. REV. 405 (2018); K-Sue Park, Money, Mortgages, and the Conquest of America, 41 L. \& SOC'Y INQUIRY 1006 (2016).

60. Du BoIs, supra note 59; PAUl Frymer, BlaCK AND BluE: AfricAN AMERICANS, THE LABOR Movement, AND the Decline of THE Democratic Party (2011); Goluboff, supra note 59; LeE, supra note 59; Walter White, A Man CALled White: The Autobiography of Walter White (1948); Aziz Rana, Colonialism and Constitutional Memory, 5 U.C. IRVINE L. REV. 263 (2015). 
But it is not only that the NAACP's critique of capitalism and embrace of left labor politics preceded the Garland Fund; integrating a focus on capitalism unmasks the expanding usefulness of racial violence to white supremacist statecraft. African Americans were lynched because of their race but also because violence served capitalism. According to the NAACP's leadership, lynching and mob violence used to protect white economic power and to ensure a captive Black labor force. ${ }^{61}$ Because violence was so closely tied to racism and capitalist exploitation, it seems unlikely the NAACP independently shifted its agenda away from racial violence to education. My purpose in stressing the racial violence issue is not to undermine the eventual education campaign but simply to point out there were paths not taken and to ask what that means for the types of rights we have today and how we might construct them in the future.

Finally, I want to address the last point you raised about the amount of money on offer from the Garland Fund. You point out that it was not that much compared to the grantmaking of other big foundations of that period, but the assessment of different grants is relative and contextual; what might seem like a paltry amount to one organization will be transformative to another. Numerous studies have detailed the co-optation of radical grassroots movements for seemingly small amounts of funding. ${ }^{62}$ To provide some perspective on the significance of the Garland Fund's grantmaking to the NAACP: no foundations or large donors $(\$ 1,000$ and over) contributed to the NAACP before the Garland Fund got involved in 1922. ${ }^{63}$ Wealthy donors stayed away from the NAACP because it was viewed as too radical. In comparison, the National Urban League received funding from five foundations including Rockefeller and Carnegie. The NAACP mainly fundraised through its membership and was constantly trying to raise funds in order to undertake larger projects but with little success. Thus, in consideration of the NAACP's fundraising past, the initial promise of $\$ 100,000$ (and the eventual $\sim 30,000$ ) was tremendous.

Our inquiry is historical, but it resonates in the contemporary moment as the growth in economic inequality and explosion in private philanthropies contributing to radical social movements has heightened the need to

61. See, e.g., Martha Gruening \& W.E.B. Du Bois, The Massacre of East St. Louis, 14 THE CRISIS 219 (1917); Walter White, Arkansas Race Riots Laid to Bad System, CHI. DAILY News, Oct. 18, 1919; Walter White, Massacring Whites in Arkansas, 109 THE NATION 715 (1919).

62. Robert Allen, Black AwAKening in CAPitalist America (1969); Incite!, The Revolution WiLl Not Be Funded: Beyond the Non-Profit Industrial CoMPlex (2007); ERIC KoHL-Arenas, The Self-Help Myth: How Philanthropy Fails to Alleviate Poverty (2016); Benjamin Marquez, Mexican-American Political Organizations and Philanthropy: Bankrolling a Social Movement, 77 SOC. SERV. 329 (2003).

63. Memorandum (Jan. 14, 1924) (on file with AFPS Papers, box 7, reel 4). 
understand the relationship between funders and grantees. You and I have gone back and forth about different aspects of the period covering the initial articulation of the education campaign, but I wonder if there is room for parts of both of our interpretations to exist together? The Garland Fund could have constrained the trajectory of the NAACP's agenda at a certain point, but the NAACP's leaders and foot soldiers could have also reconstructed the terms of what was possible into something so powerful that it ended up changing the course of constitutional law-in ways the Garland Fund could not have even imagined. An education desegregation litigation campaign may not have been the original plan, but it was a damn good one!

I think it is crucial to account for this story of Black rights-making through the impossible. But I would caution us not to mistake these victories gained through contestation as the goals at the beginning of the struggle. That does not denigrate the results that were ultimately achieved - it simply calls our attention to the process of struggle and how different institutions and actors mediated the development of civil rights.

At the end of the day, I think our work showcases the messiness and dynamism of focusing on funder/grantee relationships as it pertains to legal change. I continue to learn from you, and I'm excited for your book on the Garland Fund as it will add much needed background and nuance to one of the most important legal battles in civil rights legal history!

Yours,

Megan

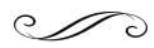

Dear Megan,

Thanks for your reply. After reading your powerful counter-arguments, I think I wish you were enjoying our disagreements a little less!

As I read it, your reply takes up three important questions I want to address: the NAACP's posture toward lynching in the mid-1920s; economic radicalism in the NAACP leadership; and the relationship between philanthropy and African-American education. As you know better than most, the themes we're taking up are central threads in the long-standing historical literature on African American political mobilization in the century after Emancipation.

First, some points of strong agreement. Archives are tricky and full of lies and half-truths, for sure, and nowhere more so than in the complicated and fraught context of racial politics. My favorite examples of this come from the War of 1812, when newspapers in the Chesapeake ran stories describing 
dastardly British efforts to steal enslaved persons for sale in the West Indies. A naïve reader encountering such stories in the archive might think these old stories recounted a truth. In fact they were propaganda efforts designed to deter the region's slaves from running off for freedom with British raiding parties. ${ }^{64}$ Another example comes from your side of the disciplinary street: political scientists in the tradition of Leo Strauss have long studied esoteric language that conveys hidden meanings to specialized audiences. ${ }^{65}$ So for sure, the archives of the 1920s are full of strategic communication and selective self-presentation, though I suppose of a very different kind than Straussians usually study. I'm happy to follow you and call it codeswitching. There's little doubt in my mind that the student of American race politics needs to be on the look-out for people switching and swerving between idioms to satisfy the strategic imperatives of the moment. ${ }^{66}$

I also agree wholeheartedly that Moore $v$. Dempsey plays a crucial and often under-estimated role in orienting the NAACP. ${ }^{67}$ After the Dyer Antilynching Bill failed in the Senate late in 1922, the Supreme Court's early 1923 decision in Moore suggested to men like Johnson and White that litigation might be more promising than electoral politics. Moore plays a significant role in my in-progress book on the Garland Fund. ${ }^{68}$

Yet there are, as you say, some persistent points of disagreement in our accounts.

\section{The NAACP and Lynching in the mid-1920s}

My own reading of the NAACP's internal correspondence and records, as well as its public materials, is that the attention it paid to the lynching problem diminished between the failure of the Dyer Bill in 1922 and the Garland Fund's grant in 1930. The anti-lynching campaign, which notably itself had begun in 1916 in response to a gift offer from wealthy white lawyer Philip G. Peabody, ${ }^{69}$ had completed its cycle with the Dyer Bill

64. John FABIAN WitT, LinCOLN's CODE: THE LAWS OF WAR In AMERICAN HiSTORY 73 (2012); see also Sylvia Frey, WATER From the Rock: Black Resistance in a ReVOlutionary Age (1991). 65. Leo Strauss, Persecution And the Art of Writing (1952); see also Arthur M. Meltzer, PHILOSOPHY BETWEEN THE LINES (2014).

66. A foundational text in this for me has been Robin D. G Kelley, "We Are Not What We Seem: Rethinking Black Working-Class Opposition in the Jim Crow South, 80 J. AM HIST. 75 (1993).

67. 261 U.S. 86 (1923)

68. The facts underlying the Moore decision offer one of the starkest examples of the connection you draw between racial violence and economics. The murder of upwards of 200 black sharecroppers in Arkansas in 1919 was part of a concerted effort to seize the cotton in the fields at a moment in which the price of cotton on world markets had skyrocketed. You write that such violence supported "racial capitalism" and that the "violence served capitalism." I don't know that I can unpack this assertion here. But there is no doubt that racial violence and lynching often advanced the economic interests of many white southerners. See Richard C. Cortner, A Mob InTEnt on Death: The NaAcP And the ARKANSAS Riot CASES (1988); ROBERT WHITAKER, ON THE LAPS OF GODS: THE RED SuMMER OF 1919 AND THE STRUGGLE FOR JuSTICE THAT REMADE A NATION (2008); NAN ElizABETH WOODRUF, AMERICAN CONGO: THE AFricAN AMERICAN FrEEDOM STRUGGLE IN THE DELTA (2014).

69. Christopher Waldrep, African AMERicans Confront Lynching: Strategies of 
episode. It is a hard thing to say that attention to brutal and harrowing public murders diminished. The horror of each new lynching remained then and remains now. The threat and the reality of violence persisted, and the fact of any lynchings at all is a dreadful thing. But the NAACP's own count of lynchings led them to believe that the numbers were dropping precipitously during the period, by more than $50 \%$ and then by more than $90 \%{ }^{70}$ The kind of mass public spectacle lynching that marred earlier decades nearly disappeared..$^{71}$

For me, valuable evidence of the NAACP's shifting internal priorities comes in 1926 when we can see what they did with their own money when they had choices. In that year, the NAACP leadership set aside its antilynching resources. Johnson and White transferred funds earmarked for anti-lynching to a savings account for future use. By the mid-1920s, in other words, the NAACP leadership was no longer spending its own available anti-lynching money, let alone asking for more such money from others. Opposition to lynching remained a top priority in many respects. But I take it that leaders like Johnson and White were choosing to save anti-lynching funds for a rainy day. ${ }^{72}$ There is no evidence that Du Bois objected. Indeed, the more radical $\mathrm{Du}$ Bois became, the less interest he had in what he characterized as the NAACP's traditional anti-lynching work. ${ }^{73}$

\section{Economic Radicalism and the NAACP's Compromises with the World}

I also want to express caution about your attribution of economic radicalism to the NAACP leadership in the 1920s. Many readers will recall the infamous 1931 clash between the NAACP and the Communist Party over the Scottsboro Boys case. The differences between the two organizations rested on their deep disagreements over radical economics. ${ }^{74}$ A similar contest between the two groups took place the year before when they competed for the grant that the Garland Fund ultimately made to the NAACP. ${ }^{75}$ There were, to be sure, underappreciated African American critics of capitalism in the 1920 s United States. But most Black critics of

\footnotetext{
RESistanCE FROM THE CIVIL WAR TO THE CIVIL Rights ERA 66-68 (2009); RoBERT L. ZANGRANDO, THE NAACP CRUSADE AGAINST LYNCHING, 1909-1950, at 28-29 (1980).

70. Memorandum from James Weldon Johnson on the Policy of the Fund as it Relates to the Negro as a Minority Group (May 15, 1924) (on file with AFPSR, box 49, reel 31).

71. Amy Louise Wood, Lynching ANd Spectacle: Witnessing Racial Violence in America (2009).

72. ZANGRANDO, supra note 28 , at 84 .

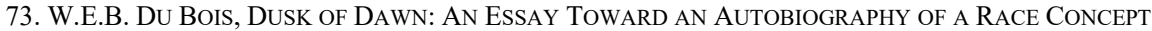
290 (1940) ("The bulk of my colleagues saw no essential change in the world. It was the same world with the problems to be attacked with the same methods as before the war. All we needed to do was continue to attack lynching, to bring more cases before the courts, and to insist upon our full citizenship.").

74. Dan T. Carter, Scottsboro: A Tragedy of the American South (rev. ed. 2007); James GOOdMAN, STORIES OF SCOTTSBORO (1994).

75. LEVY, supra note 46, at 335-37.
} 
capitalism on the left were emphatically not in the NAACP. ${ }^{76}$

James Weldon Johnson, who led the organization through the 1920s, came out of the 1910s (as left-leaning NAACP director Mary White Ovington said) "hopelessly reactionary on labor."77 Johnson told the Garland Fund's economic radicals that the labor movement and left economic proposals "touch the Negro in hardly more than an indirect way."78 Johnson himself rejected most left economic views. And even though he worried that "the great majority of Negroes" did not pay sufficient attention to "the economic basis of the Negro's condition," he still discouraged African Americans from pursuing radical economic politics. ${ }^{79}$ Indeed, Johnson wrote a book contending that economic revolution would have no effect on the racial problem at all. Changing the problem of racial attitudes, he argued, would be an independent effort "whatever form the government might take on." 80 Johnson's deputy and successor Walter White famously made his commitments clear when he broke sharply with Du Bois over economic questions in the early 1930s. ${ }^{81}$

There were exceptions, to be sure. NAACP insider William Pickens was an economic radical. Pickens had been trained in labor radicalism at Brookwood College, which the Garland Fund supported. ${ }^{82}$ The Garland Fund relied on Pickens's advice. But the NAACP often did not, largely rejecting Pickens's suggestions in 1927 to shift attention toward "working people and labor groups" within the African American community and ignoring his urgent suggestions to get more heavily involved in the Scottsboro affair. ${ }^{83}$

And of course, Du Bois would eventually make a historic turn into economic radicalism that would lead to his break with the NAACP and his departure from The Crisis in 1934. But his views about economic questions had evolved substantially between the mid-1920s and the famous split. ${ }^{84}$

76. Cedric J. Robinson, Black MarXism: The Making of THE Black Radical Tradition 197 (new ed. 2000) (describing "the Black elite" and the NAACP as "ideologically reactionary"); RoBIN D. G. Kelly, Hammer and Hoe: Alabama Communists During the Great DePression 181 (2015 ed.) (describing tensions between working-class and communist African-Americans and the NAACP's middle-class membership). This is not to say that the NAACP never took up the cause of black labor. See, e.g., Bernard Eisenberg, Only for the Bourgeois? James Weldon Johnson and the NAACP, 19161930, 2 PHYLON 110, 110-24 (1982).

77. LEVY, supra note 46, 185.

78. Johnson, supra note 70.

79. Letter from James Weldon Johnson to Jacob Baker, Vanguard Press (n.d.) (on file with JWJP, box 2 , folio 33).

80. James Weldon Johnson, Negro Americans, What Now? 10 (1934).

81. Sullivan, supra note 6; EdWARD WALDRON, WALTER White AND THE HARLEM RENAISSANCE (1978); WHITE, supra note 60.

82. Sheldon Avery, Up from Washington: William Pickens and the Negro Struggle for EQUALITY, 1900-1954 (1989).

83. LEVY, supra note 46, 220-21; SULLIVAN, supra note 6, at 147-53.

84. W.E.B. Du Bois, The Autobiography of W.E.B. Du Bois: A SoliloquY on Viewing My Life FROM THE LAST DECADE OF ITS FIRST CENTURY 290, 308 (1968) (contrasting his views on communist economics in 1926 and 1934). 
Biographers like David Levering Lewis rightly cite the Scottsboro episode as the source of Du Bois's engagement with left economic critiques of capitalism. ${ }^{85}$ His trip to the Soviet Union in 1928 played a role as well. ${ }^{86}$ But the Garland Fund also nudged Du Bois and other NAACP leaders toward a kind of provisional, tactical economic radicalism. The NAACP pitched its grant applications in a way to appeal not so much to the education interests of the Fund (the fund was not especially interested in education) but to the Fund's labor radicalism. Even this tactical adoption of economic radicalism by the NAACP leadership would give way once more in the 1940s and 1950s under the pressure of the Cold War and the views of a new generation of leaders. ${ }^{87}$ And as for the 1920s, Du Bois's retrospective analysis of the situation seems definitive. "The crusade waged by the National Association for the Advancement of Colored People from 1910 to 1930," he wrote looking back from 1940, was "one of the finest efforts of liberalism to achieve human emancipation." But the NAACP's liberalism, Du Bois contended, was insufficient precisely because it "had for its object simply free entrance into the present economy of the world." The NAACP, Du Bois commented, had no theory of "the tyranny which now dominated industrial life." 88

All that said, I think nonetheless that the question of the NAACP leadership and radical economics brings us to a deep insight at the core of your account, one that is worth drawing to the surface.

"I cannot help but wonder," you write, "in a world - a different worldthat did not limit the full arc of Black freedom dreams, what else could have been possible?" Now we're at the heart of the matter. The NAACP leadership did not arrive at its non-radicalism in a first-best world. Far from it. Men like Johnson and White took some parts of the world as they found them. From where they stand, taking on capitalism alongside racism seemed likely to add to their burdens, not solve them. Dealing with Jim Crow seemed difficult enough. There is no evidence that they secretly held more radical views than they expressed. But like all of us, their views were forged in the cauldron of the world, with its many pressures and constraints. Their projects undoubtedly reflected compromises that the world pressed on them. They worked with a world that was profoundly not of their own making - indeed, a world that had been made to subordinate them.

\section{Foundations, Capture, and Cooptation}

The literature on African-American education in the South is centrally

85. LEWIS, supra note 47, at 256-65 (2000); see also SULLIVAN, supra note 6, at 155.

86. Du BoIs, supra note 73, at 287 ("Never in my life have I been so stirred as by what I saw during two months in Russia.") 87. SUllivan, supra note 6, at 370; see also GoluBOFF, supra note 4. 88. Du BoIs, supra note 73 , at 288-89. 
occupied with precisely the kinds of questions you have raised about philanthropy and its influence. ${ }^{89}$ Examples of capture and influence abound in the story of Black education in the South. Soon after the end of the Civil War, the Peabody Fund denied its considerable financial resources to public school systems adopting racially mixed schools. ${ }^{90}$ Northern philanthropy pushed segregated Black education in the direction of industrial-style training. ${ }^{91}$ Leading voices in the literature contend that philanthropists' attention to education itself served alternately to "fit the freedmen to a new form of servitude" or to distract the Black community from more effective means of advancement such as politics and economic development. ${ }^{92}$

There is even a family connection here. Roger Baldwin's uncle William $\mathrm{H}$. Baldwin, Jr., is one of the central figures in the education philanthropy literature. The senior Baldwin served as a trustee at Tuskegee and earned the scorn of Du Bois for efforts to limit the kinds of education received by African-American youth to Tuskegee-style industrial education rather than the liberal arts. ${ }^{93}$

By the time the Garland Fund came along, leading figures in the NAACP had already clashed with some of the biggest philanthropic foundations in the country. Thomas Jesse Jones led the Phelps-Stokes Fund, which made him perhaps the leading figure in philanthropy for Black education in the United States. In 1918, Du Bois condemned Jones as aiming to "deliberately shut the door of opportunity in the face of bright Negro students." 94 A few years later, Du Bois tangled with wealthy Wall Street lawyers L. Hollingsworth Wood and Paul Cravath over efforts by the Rockefeller-

89. See, e.g., ANDERSON, supra note 18; HiLARY GREEN, EDUCATIONAL RECONSTRUCTION: AfRiCAN AMERICAN SCHOOLS IN THE URBAN SOUTH, 1865-1890 (2016); Donald G. Nieman, Introduction to AFRICAN AMERICANS AND EdUCATION IN THE SOUTH, 1865-1900, vii-xi (Daniel Nieman ed., 1994); James D. Anderson, Northern Foundations and the Shaping of Southern Black Rural Education, 19021935, 18 HIST. ED. Q. 371, 371-96 (1978); Fitchue, Locke and Du Bois: Two Major Black Voices Muzzled by Philanthropic Organizations, 14 J. BLACKS HigHER ED., Winter 1996-1997, at 111, 111 16; Marybeth Gasman, W.E.B. Du Bois and Charles S. Johnson: Differing Views on the Role of Philanthropy in Higher Education, 42 HIST. ED. Q. 493 (2002); J. M. Stephen Peeps, Northern Philanthropy and the Emergence of Black Higher Education - Do-Gooders, Compromisers, or CoConspirators?, in AFRICAN AMERICANS AND EDUCATION IN THE SOUTH, supra, at 293-309.

90. William P. Vaughn, Schools for All: The Blacks and Public Education in the South, 1865-1877, 142-58 (1974); F. Bruce Rosen, The Influence of the Peabody Fund on Education in Reconstruction Florida, 55 FLA. HIST. Q. 310-20 (1977); William P. Vaughn, Partners in Segregation: Barnas Sears and the Peabody Fund, 10 CIVIL WAR HIST. 260, 264-68 (1964).

91. See, e.g., ANDERSON, supra note 19, at 70-78; BUTCHART, supra note 19.

92. Anderson, supra note 19; Butchart, supra note 19; John DitTMER, LocAl People: The StRUGGLE FOR CIVIL RightS IN MississipPi $37-38$ (1994); Jennings L. Wagoner, Jr., The American Compromise: Charles W. Eliot, Black Education, and the New South, in EDUCATION AND THE RISE OF THE NEw SOUTH, 26-46 (Ronald K. Goodenow \& Arthur O. White eds., 1981); Fairclough, Being in the Field of Education, and Also Being a Negro ... Seems Tragic: Black Teachers in the Jim Crow South, 87 J. AM. Hist. 65, 65-91 (2000).

93. ERic ANDERson \& Alfred A. Moss, Dangerous Donations: Northern Philanthropy AND SOUTHERn EDUCATION 64-65 (1999) (interestingly, Anderson and Moss defend the elder Baldwin from some of Du Bois's criticisms); ANDERSON, supra note 19, at 82.

94. W.E.B. Du Bois, supra note 30, at 175-76. 
financed General Education Board to take control of the historically Black Fisk University in Nashville. ${ }^{95}$

The Rockefeller's General Education Board dwarfed the tiny accounts of the Garland Fund. By 1909, John Rockefeller, Sr., had donated \$53 million to the GEB. ${ }^{96}$ In the early 1930s, GEB grants totaled $\$ 5.5$ million each year. ${ }^{97}$

Yet even with the biggest fortunes in the world, the literature on philanthropy and education now increasingly attends to the ways in which beneficiaries such as Black educators co-opted philanthropists' projects for their own. Horace Mann Bond and other Black educators, as one recent historian puts it, "used the foundations for his own purposes." In the industrial education programs favored by white philanthropists, Black educators often added precisely the kinds of liberal arts content that industrial education aimed to foreclose. (Segregation helped in at least one respect, since it offered a kind of freedom from white surveillance. ${ }^{98}$ )

Of course, the politics of educational philanthropy are exceedingly complex and double edged. Philanthropists set an agenda, which Black educators in part subverted. Teachers, as Glenda Gilmore has suggested, functioned as "double agents" in the politics of race. And indeed the literature is racing to add the contributions of Black teachers alongside white philanthropists. ${ }^{99}$

Capture seems to me to be a complex two-way street. The Garland Fund nudged the NAACP toward radical economics and labor organizing. In turn, savvy actors in the NAACP pushed the Fund toward education. The result was an amalgam of multiple agendas, one that careered through the middle of the twentieth century and whose after-effects still reverberate today.

Yours,

John

95. Donald Johnson, W.E.B. DuBois, Thomas Jesse Jones and the Struggle for Social Education, 19001930, 85 J. Negro Hist. 71, 71-95 (2000); David Levering Lewis, W.E.B. Du Bois: The Fight for Equality and the American Century, 1919-1963, at 133-40.

96. Henry Allen Bullock, A History of Negro Education in the South: From 1619 to the PRESENT 122 (1967).

97. John Ensor Harr \& Peter J. Johnson, The Rockefeller CEntury: Three Generations of AMERICA'S GREATEST FAMILY 195 (1988).

98. Wayne J. Urban, Black Scholar: Horace Mann Bond, 1904-1972 (1992); Wayne J. Urban, Philanthropy and the Black Scholar: The Case of Horace Mann Bond, 58 J. NEGRO ED. 478, 478-93 (1989).

99. BUTCHART, supra note 19; FAIRCLOUGH, supra note 19; GREEN, supra note 84; WILLIAMS, supra note 19; see also James D. Anderson, Ex-Slaves and the Rise of Universal Education, in EDUCATION AND THE RISE OF THE NEW SOUTH, supra note 92, at 1, 1-25; Howard N. Rabinowitz, Half a Loaf: The Shift from White to Black Teachers in the Negro Schools of the Urban South, 1865-1890, in AFRICAN AMERICANS AND EDUCATION IN THE SOUTH, 1865-1900, supra note 89, at 313-42. 